\title{
Bangladeshi migrant associations in Italy: transnational engagement, community formation and regional unity
}

\section{Mohammad Morad \& Francesco Della Puppa}

To cite this article: Mohammad Morad \& Francesco Della Puppa (2018): Bangladeshi migrant associations in Italy: transnational engagement, community formation and regional unity, Ethnic and Racial Studies, DOI: 10.1080/01419870.2018.1515441

To link to this article: https://doi.org/10.1080/01419870.2018.1515441

Published online: 10 Sep 2018.

Submit your article to this journal ¿

View Crossmark data ¿ 


\title{
Bangladeshi migrant associations in Italy: transnational engagement, community formation and regional unity
}

\author{
Mohammad Morad ${ }^{a, b}$ and Francesco Della Puppa ${ }^{c}$ \\ aDepartment of Philosophy, Sociology, Education and Applied Psychology, University of

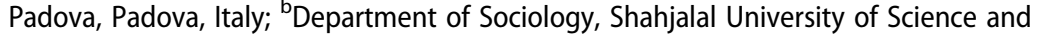 \\ Technology, Sylhet, Bangladesh; 'Department of Philosophy and Cultural Heritage, Ca' Foscari \\ University in Venice, Venice, Italy
}

\begin{abstract}
Referring to the case studies of two cities in Northern Italy, this article seeks to understand how Bangladeshi migrants use associations to seek transnational "ways of belonging" and "ways of being". It analyses how this transnational attachment to their home country has played an important role in building their own "community". The findings reveal that Bangladeshi migrant organizations work to maintain "transnational ways of belonging" by enabling migrants to retain their cultural roots; this is reflected in their observation of festivals, national days, and other practices and rituals. Although, as a relatively new migrant community, they do not share as many economic links through these associations as many other "diasporic" organizations, migrants widely express a sense that these economic connections are with their country of origin. However, there is competition within the community based on regional origin, as well as have many ambivalences and contradictions.
\end{abstract}

ARTICLE HISTORY Received 10 October 2017; Accepted 14 August 2018

KEYWORDS Migrant association; ways of being; ways of belonging; community formation; transnationalism; Bangladeshi migration

\section{Introduction}

There has been renewed interest in migrant associations among migration scholars (Glick Schiller, Basch, and Szanton-Blanc 1995; Olwig 2003; Schrover and Vermeulen 2005). Researchers hold the view that migrants establish different associations, mainly based on their country of origin, home towns, common cultural heritage, ethnicity, language and religion, which play an important role in their lives (Sardinha 2005). Even though such associations help with the settlement process, they maintain a certain level of transnational engagement with their country of origin, where the cultural issues rooted in 
their homelands are often central to their aims (Owusu 2000). They work to preserve familiar practices and values by observing the national days and festivals of their home countries, and by organizing ethnic sports, folk dancing and gatherings (Marquez 2001). Through associations, migrants also work to retain what they perceive and present as their "religious identity", ${ }^{1}$ which could be distinguished from other migrant groups belonging to the same religion by language and specific practices (Akcapar 2009).

Some associations also work as transnational actors in the development of their country of origin (Rex, Danièle, and Czarina 1987; Glick Schiller, Basch, and Szanton-Blanc 1995; Faist 2008; Akcapar 2009) by maintaining various links. These include mobilizing and transferring financial capital, resources and knowledge in order to provide relief and rehabilitation following a natural disaster or any other kind of emergency, as well as providing regular support to several sectors, such as health, education and infrastructure development in their natal villages and towns of origin (Guarnizo 2003; Cheran 2004). In so doing, migrant associations create a new sense of community among their members (Sardinha 2005; Orozco and Rouse 2013).

Regarding migrant associations in Italy, there have been no systematic studies to date on the topic, although it should be underlined that there has been some regional insight in areas of higher immigration (Caselli 2006). Mantovan (2007) categorizes studies on the self-organization of migrants in Italy in three areas: those that focus on participation by institutional means (Attanasio and Facchini 2004); those that focus on migrant associations (Palidda and Consoli 2006; Camozzi 2008); and those that take into account different types of participation (Kosic and Triandafyllidou 2005). As part of his analysis comparing nativist policies and social commitment in favour of irregular migrants, Ambrosini (2014) explores the relationship between the activism of Italian civil society and migrant associations, investigating the reasons for their weakness (Boccagni 2012). Using the concept of "political opportunity structures", some scholars analyse the way in which migrant associations in Italy function and develop over time (Pirkkalainen 2013), as well as how these associations cope with development issues and the impact of these activities in terms of new forms of citizenship. These new forms of citizenship refer to transnational dimensions, which also represent the framework within which this article is placed. In fact, we observe that Bangladeshi associations in Italy are a form of bottom-up transnationalism and a constitutive element in the construction of a collective transnational identity.

Despite this growing scientific interest in the so-called "Bangladeshi diaspora" (Alexander, Joya, and Jalais 2016), existing empirical research on international migration from Bangladesh has not taken significant account of the engagement of migrant associations. However, some studies (Eade, Fremeaux, and Garbin 2002; Kibria 2011) have indicated that Bangladeshis 
have formed various associations in the USA and the UK, which are mainly based on their districts, villages and towns of origin. Nevertheless, it is true that the USA and the UK have a long history of Bangladeshi migration and that bigger Bangladeshi communities have already been established there (Gardner 1995; Kibria 2011). However, it could be interesting to know, as they are a relatively new migrant group in other European countries, why Bangladeshis form their own associations and how these organizations help them to sustain their transnational engagement.

This article refers to the case studies of two towns in Northern Italy, which recently emerged as major destinations for Bangladeshis. It looks at the reasons why Bangladeshi migrant organizations form and the activities they carry out in the framework of a transnational perspective. It also analyses how their transnational activities help them to form a "community" in the destination society. The main research questions here are threefold: (1) How do Bangladeshi migrants in Italy maintain a transnational engagement with their country of origin through associations? (2) How do they mobilize, organize and build their own Bangladeshi community in their host society through these associations? (3) What critical aspects do their associations face?

Sociological and anthropological research has suggested various definitions of transnationalism. Nonetheless, the widely cited definition of this concept is provided by Basch et al. (1994, 7): "the process by which immigrants forge and sustain simultaneous multi-standard social relations that link together their societies of origin and settlement". In this way, Glick Schiller, Basch, and Szanton-Blanc $(1995,49)$ have indicated that transnationalism is the "diminished significance of national boundaries in the production and distribution of objects, ideas, and people". Drawing on Levitt and Glick Schiller's (2004) distinctions between "ways of belonging" and "ways of being" in the transnational social field, this article analyses the transnational engagement of Bangladeshi associations. According to Levitt and Glick Schiller, the term "ways of belonging" implies practices that indicate a conscious connection between a specific migrant group and their country of origin. According to them, "these actions are not symbolic but concrete, visible actions that mark belonging, such as wearing a Christian cross or Jewish star, flying a flag, or choosing a particular cuisine" $(2004,1006)$. This indicates both combined actions and an awareness of a kind of identity. On the contrary, the term "ways of being" highlights migrants' cross-border social relationships and practices, rather than identities associated with their actions. Through these transnational attachments, migrants create their own transnational social field - an interlinking network of social relationships through which ideas, practices and resources are irregularly exchanged, organized and transformed in a way that transects borders (Levitt and Glick Schiller 2004). When considering migrant associations as a particular space, it could be interesting to see how they express both ways of being and ways of belonging in the transnational social field. 
The article begins by providing an overview of the context of this study. It then goes onto highlight its methodology. The subsequent sections present and discuss the findings and analysis in relation to the typology of Bangladeshi associations, their transnational engagement and "community formation". 2 Before the conclusions, the article analyses the ambivalent and contradictory aspects within the Bangladeshi associations in Padova and Cadoneghe and in their relationship with the local political forces and institutions.

\section{Context}

Bangladeshi migration to Italy is a recent phenomenon. Bangladeshi migrants arrived during the 1980s due to the closure of other European countries' borders (Priori 2012; Della Puppa 2014; Morad and Gombač 2015), but the country qualified as an important destination for the Bangladeshi migration during the 1990s. Today, the Bangladeshi community numbers almost 120,000 individuals (Della Puppa and King 2018). Probashi - the Bangla term for "emigrants" - in Italy were initially concentrated almost exclusively in Rome (ninety-two per cent) (King and Knights 1994). Indeed, the Italian capital exercised a great power of attraction over them given the presence of fellow countrymen, pioneers of this migration, who were strengthening the networks and offering the first support to newcomers, and the fascinating imagery that it evoked among the middle-class educated youth of the world's peripheries. The main reasons, however, were the work placement opportunities in the context of the informal economy (services, catering, tourism, small business, etc.) and the possibility of mimesis within the dense mesh of a community of fellow countrymen, which the metropolis initially offered to migrants without a valid residence permit. On obtaining a regular residence permit through one of the many amnesties that characterized Italian migration policies during the 1990s (King and Knights 1994; Zeitlyn 2006; Priori 2012), they moved and obtained work and stable housing across the country. Subsequently, different "Banglatowns" came into being in many areas of the province, usually close to major industrial centres in the northern regions (Della Puppa 2014). This has also been the case for Padova and Cadoneghe. The establishment of a Bangladeshi community in the Province of Padova started during the mid-1980s (Morad and Gombač 2018). Bangladeshis are now the sixth largest non-European community in the Province of Padova, with 1,661 individuals out of 95,083 foreign residents (Morad and Gombač 2018). In Padova, as well as in the rest of Italy, the Bangladeshi community grew because wives joined their husbands, who had migrated earlier. In fact, it must be underlined that the first generation of probashi in Italy was almost entirely composed of men. Therefore, family reunifications in the first phase of Bangladeshi migration to Italy were configured exclusively as "male" reunifications. Usually, the first-generation migrant, after meeting the 
necessary conditions, returned to his country of origin to marry - usually via an arranged marriage - a woman who, soon after the wedding, was reunited with him in Italy (Della Puppa 2018). Although there are rare cases of intermarriage, usually with Italian women, the vast majority of marriages involving the first generation of Bangladeshis in Italy are endogamous.

The social, occupational, family and administrative trajectories, as well as the class background, of the probashi in the community of Padova and Cadoneghe coincide with those of the protagonists of other studies on the Bangladeshi migration in Italy (King and Knights 1994; Zeitlyn 2006; Priori 2012; Della Puppa 2014). In fact, they are mainly men from the upper-middle class, with a higher education qualification: sons of lawyers, landowners, teachers, entrepreneurs, public administration employees, military officers and managers, who grew up in wealthy families in post-independence Bangladesh and are today working as unskilled workers, inclined to work overtime and categorized by low-profile contracts in factories in the industrial district of the Province of Padova. They do not correspond to the working class in their country of origin, and the work they do in Italy "they would never dream of doing in their home country" (Zeitlyn 2006, 32). This distance between their social position in the country of origin and the country of destination, as will be explained below, results in an apparently contradictory political orientation of many probashi.

Industrial employment characterizes the Bangladeshis in the northern regions of the country. Although obviously a more widespread phenomenon in Northern Italy, the community in Rome is mainly characterized by those who work in the hotel and restaurant sector, as well as owners of groceries, Bangladesh travel agencies and Internet cafés - and the tertiary sector, in general.

Finally, Bangladeshis in Italy are mainly regular migrants from a legal status point of view (Della Puppa 2014) and the first generation of probashi in Italy have lived in the country long enough to acquire Italian citizenship (Della Puppa and King 2018).

\section{Methods}

The empirical material for this article consists of 25 in-depth interviews and a 13 months of participant observations. The fieldwork was carried out in two phases, the first between September 2012 and March 2013 and the second between November and April 2016, in the Municipalities of Padova and Cadoneghe, in the Province of Padova, Italy. The interviewees were accessed mainly using the "snowball" method. We tried to select our respondents from both groups, i.e. Bangladeshi migrants affiliated with Bangladeshi associations as leaders and members in these two cities, and earlier Bangladeshi migrants who were not involved in associations, but who have certain ideas 
about them. All of the interviews were conducted in Bangla. The interviewees' names are fictitious.

\section{A typology of the associations}

Even though Bangladeshis have been in Padova since the mid-1980s, they began to establish their own associations from 2002 onwards. Bangladeshi migrants in Padova have organized themselves into different associations.

In general, these associations fall into two broad categories: associations based on their homeland and associations based on migrants' regional origins.

Homeland-based associations comprise all Bangladeshis, regardless of their regional origin in Bangladesh. There are five associations of this type: Associazione Bangladeshi di Padova, also known as "Bangladesh Samity"; Associazione Shabuz Bangla; Bangladesh Islamic Cultural Centre; Rangdonu; Bangladeshi Cricket Club of Padova. It is worth mentioning that Bangladesh Samity was established to serve as an umbrella organization to unite Bangladeshis of all regional backgrounds. Bangladesh Samity, Shabuz Bangla and the Bangladesh Islamic Cultural Centre are the largest and most pioneering Bangladeshi migrant associations in Padova. These associations are mainly involved in several activities in which the entire Bangladeshi community in Padova is involved.

The regional associations are established on the basis of their area of origin, which is measured by the formal district boundary. ${ }^{3}$ We identified four associations that belong to this category: Comilla Samity; Dhaka Samity; Sylhet Samity; Noakhali Samity. However, unlike the homeland-based associations, these regional associations are not registered with the municipality; rather, they seem to be more informal associations. These associations tend to have a much smaller membership and activities compared with Bangladeshi national organizations.

Finally, it should be underlined that, apart from these types of associations, some of the Bangladeshis in Padova have informally opened up branch offices of two major Bangladeshi political parties: the Awami League and the Bangladesh National Party. However, the majority of people from the Bangladeshi community in Padova do not appear to be involved with these organizations. In particularly, it has been shown that the followers of these political parties sometimes sit together in other associations in Padova, which suggest that associations are not based on loyalties related to politics in Bangladesh.

\section{Transnational engagement of Bangladeshi migrant associations}

\section{Social and cultural activities: transnational "ways of belonging" to the homeland}

The establishment of Bangladeshi associations, mainly homeland-based ones, are aimed at the preservation, expression and transmission of "Bangladeshi 
culture". Inevitably, then, their main activities involve the celebration of all Bangladeshi national days, e.g. Ekushey February (Mother Language Day), 26 March (Independence Day) and 16 December (Victory Day). They also celebrate Bengali New Year (Boishakhi Mela), which is observed in Bangladesh at the start of the monsoon season. In this regard, Humyun, President of Bangladesh Samity, stated the following:

The purpose of this association is to keep our ethnic culture and to observe our national festivities. I would say that 21 February [Mother Language Day] is very important to us as it is our big day of mourning. We observe it here in Padova. Besides, we arrange Pohela Boishakh [Bengali New Year] and observe 26 March [Independence Day] and 16 December [Victory Day]. (Humyun)

It should be emphasized that what Humyun describes as "ethnic culture" is, in reality, the outcome of a narration, a self-representation and a self-narration that can be motivated by different purposes, which, as will be show, can lead to contradictory and unexpected results.

However, study participants affiliated with other homeland-based associations, especially Rangdonu and Shabuz Bangla, also mentioned that cultural activities constitute the primary purpose of their bodies. Their goal is the promotion of a cultural "Bengaliness" (Eade and Garbin 2006). On occasion, they present Bangladesh's diverse culture through different events, including Bangla music, dance, exhibitions of arts and crafts, and food festivals. Some special events are also arranged by these associations. In Ekushey February, they go to Shahid Minar, the monument to the language martyrs (Monument of Martyrs) constructed by the Bangladeshi community in Breda Park, Cadoneghe, and pay homage by laying flowers on it. Moreover, on Independence and Victory Days, singing the Bangladeshi national anthem, giving speeches and reciting Bangla poems take place, while sport events and painting contests for children are organized. As such, it could be argued that the transnational ways of belonging for the Bangladeshi migration are maintained in their host country through the observation of various days and festivals related to their common origin and the national history of their homeland (Vertovec 1997). Such activities thus demonstrate their "emotional, historic and imaginative link to Bangladesh's liberation struggle, and to the nation that emerged from it" (Alexander 2013, 591), while these activities express their sense of "Bengaliness".

In addition, homeland-based associations arrange occasional music performances to fulfil the cultural needs of the community. Renowned Bangla rock and folk legends from Bangladesh and the UK are often invited to perform Bengali music at these concerts. By doing so, Bangladeshi associations connect Bangladeshis in Italy with those in the UK, Bangladesh and other locations. Moreover, in order to support the community's sporting demands, some associations will often organize popular sporting events. 
Indeed, we have observed that the Bangladesh Cricket Club of Padova and Shabuz Bangla have formed their own cricket team. In summer, they play against migrants from other countries, such as Indians and Sri Lankans in Padova. Moreover, in order to meet the sporting demands of the so-called "second generation", the Shabuz Bangla association rents an indoor stadium on Saturday and Sunday evenings, where young Bangladeshis gather to play different games while wearing the jersey of the Bangladeshi national teams.

These activities work to shape ethnic awareness and promote a Bangladeshi cultural identity. This is such that second-generation Bangladeshis who are growing up in Padova can still claim this heritage, as Humyun, President of Bangladesh Samity, explained:

We are Bengali. The generations of us who came over from Bangladesh know these cultural aspects. However, our next generations who are growing up here tend to forget them. So, these programmes help to preserve our culture throughout the generations and create a sense of identity for our second generations. (Humyun)

Consistent with Humyun's quote, other Bangladeshi migrants proudly mentioned that attending these types of cultural programmes taught their children about Bangla culture. For instance, Helal, a probashi arrived in Padova in 1994, stated:

My children used to participate in Boishakhi Mela [a celebration of Bengali New Year] by wearing our traditional dress, lungi and punjabi. My younger son, who was born in Italy, has asked some questions about these festivals. I explained to him that this is our tradition and how we dress. (Helal)

It is through these association activities, as often expressed in the interviews, that the Bangladeshi cultural heritage is presented to Italians in the spirit of multiculturalism; likewise, Bangladeshis participate in the major Italian carnivals in the Municipalities of Padova and Cadoneghe, joining the carnival parades with their organizations, especially Shabuz Bangla and Rangdonu, by wearing their traditional dress. They also bring their national flag to represent Bangladesh. Here, the motivation is to present their rich cultural heritage in order to encourage Italians to adopt a positive attitude towards their homeland, as well as towards the Bangladeshi community in Padova. For Uddin, President of Shabuz Bangla:

We love to present our cultural heritage to the Italians, so they understand that we have a rich tradition and culture. Perhaps we came here for our livelihood, but we are just like them [...]. This is our objective behind participating. (Uddin)

The formation of associations is also motivated by the aim to maintain the bonds of language and religion (Cohen 2008). For instance, the philosophy behind the establishment of the Bangladesh Islamic Cultural Centre, the 
community's own religious organization, is related to the desire to maintain close contact with the religion and mother tongue of the homeland. As their language is Bangla, Bangladeshis feel the need to organize Bangla courses for children (who only speak the mother language with parents and do not know the written form) given by members of the associations and to set up their own religious centre at which religious lectures and other meetings are communicated in Bangla. Shekh, President of the Bangladesh Islamic Cultural Centre, explained:

We established this Centre because, in Padova, we used to pray at the Arabic mosque where all of the religious lectures are given in Arabic. Most Bangladeshis, especially our children, do not understand Arabic, so we felt the need for a separate mosque for our community. (Shekh)

We visited this Centre several times and saw that the imam delivered his lecture in Bengali. Because of the differences in religious practice and language with other Muslim communities in Padova, the religious identity of Bangladeshi migrants serves as an ideological-cultural base, which links them with their homeland (Akcapar 2009). It should also be stressed that, in the context of "mosque conflicts" taking place in Italy and the rest of Europe (Cesari 2005; Saint-Blanc and Schmidt di Friedberg 2005), the presence of the centre prompted many criticisms from among local political groups, which exploit the issue of migration to attract votes, and residents of the neighbourhood. However, the Bangladeshi community and its associations in Padova and Cadoneghe have not adopted any particular public or private strategies to deal with the growing Islamophobia.

\section{Economic activities: transnational "ways of being" with home}

Another key objective of the associations is the forging of economic connections with their country of origin. However, unlike other migrant associations (Guarnizo 2003; Cheran 2004), Bangladeshi national associations in Padova are not largely involved in the development of their home communities through the collective transfer of resources or philanthropic activities, although they have occasionally been involved with these types of activities. In particular, under the leadership of Bangladesh Samity, all of the national and regional associations have collectively raised funds and transferred money to their home country for relief purposes when any natural disaster has occurred in Bangladesh. They also collect monetary donations to repatriate their community members after death. Local organizations also undertake this type of initiative. The former Vice President of Bangladesh Samity stated:

We try to assist Bangladesh when disaster strikes; we sent 3000 euros during Cyclone Sidr. These money were collected from people in our community as well as from different social organizations, such as Caritas Italy. We manage 
the necessary steps to repatriate community members after death. We have spent about 3,500 euros in the past two years to repatriate five people. (Bhuiyan)

Nevertheless, regional associations sometimes become individually involved in making direct contributions to their local villages or towns of origin. In cases such as these, they collect and raise funds from among their own regional people in Padova to contribute towards relief activities during natural disasters. In common with Bangladeshi associations in the UK (Eade, Fremeaux, and Garbin 2002), they carry out fundraising activities for local schools, Madrasas, infrastructure development, building local mosques and providing scholarships to underprivileged students. However, these activities are not as frequent as those undertaken in the UK.

It could be argued that Bangladeshi migrants in Padova maintain strong "ways of belonging" to their homeland. They work to retain their cultural roots, which is reflected in their observation of festivals, national days, and other practices and rituals. In so doing, they are playing an important role in the (re)construction of the identities of Bangladeshi migrants in the transnational dimension. Even though their economic activities are not that significant, as the community in Padova is relatively new, these activities express a diffused "way of being" with their country of origin.

\section{Building a community: the main spirit is Shahid Minar and the Bangladesh Islamic cultural centre}

In the first seven years after I arrived in Italy [in 1998], I noticed that Italians thought that we were from India: they called us Indian. But, now, this has changed. Most Padovans know that we are from Bangladesh; now they call us Bangladeshi. I think this is a great achievement. We achieved this through cultural activities carried out by our associations. (Shahab)

As Shahab's quote illustrates, our participants mentioned in their interviews that their association activities have played an important role in building their own Bangladeshi community in these cities. In particular, their activities to promote cultural belonging with their country of origin distinguish them as an "ethnic/cultural" community consisting of a secular nationalist Bengali heritage (Eade and Garbin 2006; Kibria 2011; Alexander 2013). In the collective imagination of the native Italian population, India holds a more recognizable, and often stereotypical, image. For this reason, Shahab proudly affirms that the Bangladeshi community is finally recognized as being distinct from that resulting from Indian immigration by the native people. This is due to the quantitative increase in Bangladeshi migrants in Padova and, consequently, to the intensification of their relations with the local society, the active participation of Bangladeshi members of the "Municipal Council of Foreign Citizens" within the Municipal Council; ${ }^{4}$ the strong activism of the Bangladesh associations, especially during the Italian carnivals in 
Cadoneghe, the activities of the Bangladesh Islamic Cultural Centre, which has helped in depicting Bangladeshi migrants as a Muslim community, thus limiting the extent to which they are stereotypically identified with Indian Hindus.

The events arranged by their associations provide Bangladeshi migrants with ample opportunity to meet people from different regions of Bangladesh, thus helping them to feel at home:

We are not always able to meet with our families who remain in Bangladesh, but when we meet with our fellow Bangladeshis at these events, we at least get the feeling that we are perhaps meeting with our relatives back home. (Shahab)

In turn, such activities act as focal point for social networking and enhancing social relationships between fellow migrants, which is vital in the formation of a community. Moreover, Bangladeshi associations fulfil a vital judicial function in the building of these communities. They often work to resolve problems and disputes involving their members, thereby helping to maintain peaceful relations within the community. For instance, Shabuz Bangla works to resolve all kinds of personal, marital and family-related disputes in order to enable Bangladeshis to minimize disputes and avoid going to the Italian police and/or courts. In agreement with the findings of Owusu (2000), Bangladeshi associations use their traditional customs and social practices, as well as the legal and social norms of their new host society, to minimize disputes.

However, the Shahid Minar monument and the Bangladesh Islamic Cultural Centre are two visible symbols marking a place for Bangladeshis in Padova. First, collective memory and rituals of memorialization are pivotal to the formation of a transnational community. These Bangladeshi monuments, i.e. the Shahid Minar Monument of Martyrs in Padova and the rituals surrounding it, are playing an active and significant role in the formation and transformation of the Bangladeshi community in this host society (Alexander 2013). This is the third permanent Shahid Minar in Europe, which was built in 2013 at Breda Park, where the land was allocated to the community by the city council for ninety-nine years. ${ }^{5}$ Even though it was an initiative of the Shabuz Bangla association, Bangladeshi migrants in this Italian province financed this monument in its entirety (20,000 euros), regardless of their regional origin or political background. This monument is a replica of the original Shahid Minar, which was built outside Dhaka Medical College to commemorate the Bengali students and political activists who were killed by the Pakistani police when protesting against the process of Urduization in East Pakistan on 21 February 1952. The Language Movement of 1952 is considered as the starting point of Bengali nationalism. Therefore, the visibility of this monument in this Italian Province is a crucial marker of a collective identity. It also represents the Bangladeshi community in the Italian public sphere as a secular Bengali nation (Eade and Garbin 2006). 
Apart from the monument, the Bangladesh Islamic Cultural Centre has helped to represent Bangladeshi migrants as a Muslim community. The building that houses this centre was purchased by Bangladeshi migrants in Padova in 2012, who paid the sum of 350,000 euros. In addition to its daily religious activities, all types of community meetings take place at the centre, in particular, meetings of all regional associations have taken place there. It is worth mentioning that, during the Jummah and Eid prayers, the Bangladeshis have a big get-together. During Ramadan, the regional associations help the Cultural Centre to raise the funds for a free Iftar. The respondents mentioned that this gathering provides them with the feeling of being at home. The President of Bangladesh Islamic Cultural Centre commented:

During Jummah time, approximately 500 Muslims perform their prayers. If it is holiday, this number is usually bigger. During the time of Eid Namaz [prayer], approximately 1,200 people were present [...]. The overall environment was festive and we felt as though we were performing Eid with our family members in our country. (Shekh)

Therefore, this centre has made a great contribution to the formation of the Bangladeshi community in Padova. Nevertheless, there has been a great deal of conflict in the case of UK Bangladeshis with people associated with the activities related to London's Shahid Minar monument and Islamic centres. The cultural activities of Banglatown in the UK have been challenged and criticized by leaders of the East London Mosque and its affiliated organizations. Besides, the East London Mosque maintains a clear distance from the cultural activities that take place in Altab Ali Park and around the Shahid Minar monument in London. They have often interpreted these activities as un-Islamic and influenced by Western secular values and Hindu practices (Eade and Garbin 2006; Alexander 2013). Above all, the East London Mosque is supported economically by the Saudi monarchy and especially the Islamic Bangladeshi party, Jamaat-Al-Islami (Eade and Garbin 2006; Della Puppa 2014), whose leaders do not recognize such celebrations.

However, within the Bangladeshi community in Padova, there were no ideological conflicts between Bangladeshis involved with the Bangladesh Islamic Cultural Centre and the Shahid Minar monument:

You know, last year we donated 300 euros from the fund of the Islamic Cultural

Centre for a successful programme for Ekushey [21 February]. (Moin)

In fact, the Bangladeshi community leaders associated with the centre are simultaneously involved with other national associations. It seems that they also belong to Bangladeshi secular political parties, such as the Awami League and the BNP. Unlike other Islamic organizations for Bangladeshi migrants in Italy (Priori 2012; Della Puppa 2014), the Bangladesh Islamic Cultural Centre of Padova does not seem to have any formal ties with national 
and transnational religious organizations, such as the Islamic Forum Europe, in which the East London Mosque would be included. Such associative links with other parts of Italy and the rest of Western Europe would seem to have not yet developed by the relatively young Bangladeshi community of Padova, whose organizations - both the "secular" ones as well as the religious one - would mainly have contacts at the regional level. This is the case, for example, for the contacts with the organizations of the nearby community of Venice, which are based on the personal knowledge of individual members, rather than the political dispositions and modalities of understanding religious and associative practices.

Moreover, in terms of community formation, Bangladeshis in Padova also work towards unity, based on their regional origin in Bangladesh. In this regard, all of the associations that have been formed according to Bangladeshi regional origin clearly organize activities for building up regional unity. Such regional associations therefore seek to enhance relationships between their own regional people living in Padova through a variety of social gatherings, such as picnics, Iftar parties and Eid reunions. They feel the need for unity, which is essential to achieve effective leadership over the Bangladeshi community in Padova. This sentiment manifests itself in their programme to have their own people voted in during elections for the executive committees of Bangladesh Samity and the Bangladesh Islamic Cultural Centre. During this time, each local association sits with its members to select candidates and to get them elected. This is considered as a means of enhancing the status and influence of their own migrants within the Bangladeshi community. As highlighted by an executive member of Comilla Samity, who was also Vice President of Bangladesh Samity:

We formed Comilla Samity to maintain the unity of Comilla, to keep everybody united. It was so that we could get elected as representatives at Bangladesh Samity. We want to establish ourselves in leading positions. That is why we need unity. (Monjurul)

Nonetheless, this regional unity within the Bangladeshi community has also emerged from its members' regionally distinct cultural practices, which bring them much closer to their own regional people. The respondents also mentioned that, even though Bangladeshis in Padova work together as a community, their regionally distinct cultural practices mean that they have greater affinity with people from their own region, which is why they formed their own associations in the first:

Even though our roots are in Bangladesh, here in Padova, we came from different places in Bangladesh. Everybody builds their own local "Samity" to maintain a close relationship with their regional people. There are many reasons behind this. Even though we all speak in Bengali, our local dialects are different $[\ldots .$.$] . Besides, the things we like are often different to those of$ 
people from other regions; for instance, although we are all used to Bangla food, our cooking methods are different. These regional differences come from cultural differences. (Bhuiyan)

\section{Ambivalences and contradictions}

Despite the respondents' comments made in the interviews, the process of "community formation" through associations also has certain contradictory and ambivalent aspects. On the one hand, Bangladeshi migrant associations play an undeniably constructive role within the Bangladeshi community, satisfying the different material, symbolic and identity needs of its members, while, on the other, they are characterized by fractures and conflicts due to each association's struggle for "community hegemony". Indeed, not only are Bangladesh Samity and the Bangladesh Islamic Cultural Centre competing with each other on a "regional" basis in order to achieve leadership positions within their community in Padova, they are also entering into conflict over which body should be considered as the "official" association representing the Bangladeshi community to Italian society and, above all, its institutions (Priori 2010).

Furthermore, within the associations themselves, there is conflict over the decision about whom should be the leader: it is emblematic that the Rangdonu association evolved out of a split within Shabuz Bangla over issues of internal leadership.

The fragmentation of Bangladeshi associations has been fuelled, more or less consciously, by several Italian institutions, especially the Municipalities of Padova and Cadoneghe, the main trade unions and some leftist political movements. The municipalities have sought to identify a unique representative within the Bangladeshi community with whom to correspond, as though a single representative could represent the views of every Bangladeshi resident and know how every single Bangladeshi wants to be represented by the associations. This should not be linked to particular public problems and issues that would have pushed public institutions to address them, but rather to the aim of the Municipality to reassure the native population about exercising social control over "foreigners"; in a sociopolitical context, this refers to the population of North-east Italy, which is not particularly inclusive towards migrants.

The above-mentioned political forces and trade unions, in order to find a larger membership among migrant workers, have tried to establish themselves as the political reference and trustees for each Bangladeshi association. This has led to the legitimization of several Bangladeshi associations by Italian subjects, who are recognized as "institutional" subjects, which, at the same time, has seen the segmentation and clashes between the various associations.

A further contradiction is the adhesion of certain members and leaders of the Bangladeshi associations to Italian secular and leftist political movements, 
while also being involved in political activities on behalf of conservative and religious parties in Bangladesh. Acting on the local chessboard in close connection with parties such as Rifondazione Comunista ${ }^{6}$ or the social centres ${ }^{7}$ of the city does not prevent some from maintaining links with sympathizers of the Bangladeshi nationalist right. This contradiction stems directly from the belief that the issues and political categories of Bangladeshis and those of the natives are not mutually translatable. At the same time, this contradiction is partially reconcilable in light of the previously stated fact that the Bangladeshis in Italy, despite being salaried workers in their country of residence, do not correspond in any way to those in the working class in Bangladesh. Therefore, in their country of origin, they often support political parties that defend social and material interests that are divergent from those encouraging them to become politically involved in Italy.

It should be emphasized that the political institutions of Padova and Cadoneghe also strictly espouse the belief about the alleged "untranslatability" of the respective political categories. In fact, on several occasions, the administration, which is minded that it uncritically considers the migrants as a "community", in terms of a homogeneous and cohesive entity, has identified as its "natural" referent the Bangladeshi representative of the already mentioned "Municipal Council of Foreign Citizen" - or, at most, the leader of Associazione Bangladeshi di Padova. These decision by the municipality have helped to trigger tensions within the Bangladeshi community, since these "representatives", once again, do not enjoy full public recognition as "community leaders" from their fellow countrymen or have clearly displayed personalistic aims. That is, local policies are shaping the political opportunity structure and, consequently, influencing the migrant community organization (Pirkkalainen 2013).

In addition, the opaque and unintelligible representation of the self-organization of Bangladeshis has been fuelled and exploited by many association leaders, e.g. the leader of the Associazione Bangladeshi di Padova, who, by describing their "community" and associations as irretrievably fragmented along regional lines, have attempted to present themselves, including to the institutions of the City, as the only reliable "community leaders".

Thus, "the 'Bangladeshi community' has proven to be much more complex than expected, but Italian institutions have not been interested in pursuing dialogue with those with different political tendencies or understanding the logic that has created such internal contradictions" (Priori, 2010, 47).

\section{Conclusion}

This article has attempted to provide insights into the transnational engagement and community formation of Bangladeshi migrants through associations in Padova, Italy. Thus, in conclusion, the empirical findings related to our first research question indicate the following conclusions. 
Firstly, concerning "transnational ways of belonging" (Levitt and Glick Schiller 2004), we can conclude that Bangladeshi associations in Padova help Bangladeshi migrants to preserve what they perceive and represent as "Bangla identity" (Eade, Fremeaux, and Garbin 2002; Eade and Garbin 2006; Kibria 2011), which is related to the national history of their homeland (Vertovec 1997). In common with many other migrant organizations examined in several previously mentioned studies, it can be argued that Bangladeshi migrant associations have emerged from their ethnic awareness, while the main goal of their association activities is to promote their identity. Moreover, similar to Glick Schiller, Basch, and Szanton-Blanc (1995) findings on migrants from St. Vincent, Grenada, the Philippines and Haiti to the USA, we clearly observe that Bangladeshi migrant associations in Padova function as "cultural brokers" in the host society. In this regard, as with many other organizations (Owusu 2000; Marquez 2001; Kelly 2011), they represent their home country by displaying their national cultural diversity through the organization of different cultural and sporting events, the celebration of all Bangladeshi national days and festivals, and the presentation of their heritage at Italian festivals.

Secondly, with regard to "transnational ways of being" (Levitt and Glick Schiller 2004), our findings indicate that the case of Bangladeshis in Italy may be an exceptional one, since, unlike other migrant organizations, its associations focus very little on development activities in their home country through the mobilization and transfer of financial capital, resources and knowledge in various sectors, such as health, education and infrastructure development (Rex, Danièle, and Czarina 1987; Guarnizo 2003; Cheran 2004; Akcapar 2009; Orozco and Rouse 2013). Bangladeshi associations occasionally involve themselves in these types of activities, but only when natural disasters or emergency situations strike in their home country do they collect and raise funds under the leadership of Bangladesh Samity to send relief and transfer financial capital. These associations also perform fundraising activities for community-building efforts in the host society. The Bangladeshi Shahid Minar monument and the Bangladesh Islamic Cultural Centre are two examples that have been entirely financed by Bangladeshi migrants through the combined efforts of all the national and regional associations.

With reference to the second research question, our findings and observations have shown that the transnational activities of Bangladeshi migrant organizations in Italy have created a sense of community among their members (Sardinha 2005; Orozco and Rouse 2013), which distinguishes them as a "community" consisting of a secular nationalist Bengali heritage and a religious identity. In this regard, the Shahid Minar monument and the Bangladesh Islamic Cultural Centre are also two visible symbols that create a place for the Bangladeshi community in the Italian urban space. Furthermore, within the Bangladeshi community, Bangladeshi migrants associated with the centre and other associations have not experienced ideological 
conflicts as has been common with Bangladeshi associations in the UK (Eade and Garbin 2006; Alexander 2013). However, there is competition based on the regional origin of migrants and the personal interests of different individuals and groups. Moreover, the lack of knowledge of the intracommunity dynamics, the Bangladeshi political landscape and an "orientalist" attitude have led local institutions and political forces to exacerbate the fractures within the Bangladeshi associations. A further important element in understanding the association dynamics of Bangladesh migrants, but ignored by Italian local institutions and political groups, is the gap between the class positioning of migrants in Italy and that in their country of origin (Della Puppa 2014). This social distance explains the apparent contradiction in which migrants may be simultaneously involved, in different transnational contexts, in political activities and in movements of opposing orientation (Priori 2010).

Although the limitations, ambivalences and contradictions, Bangladeshi associations in the Province of Padova represent the path of a specific component of first-generation Bangladeshi migrants in the north-east of Italy. If and how this situation may be developed by newer generations born and socialized in Italy is yet to be determined.

\section{Notes}

1. We are aware that what is perceived and represented as "religious identity" within the migration experience is often reinvented or invented, tout court (Eade, Fremeaux, and Garbin 2002; Eade and Garbin 2006; Kibria 2011).

2. We are aware of the social stratifications and political divisions running through what we have called the "Bangladeshi community" in Padova and we do not want to propose a homogeneous, compact and uniform representation.

3. Bangladesh is divided into 65 districts.

4. The Municipality of Padova established, within the Municipal Council, a council of migrants with a purely advisory function.

5. In Europe, the first permanent Shahid Minar monument was built in London, the second was erected in Bari.

6. The former Italian Communist Party.

7. Self-managed Social Centres (centri sociali autogestiti) are empty buildings (former factories, warehouses, shop floors etc.) occupied by activists and transformed into "autonomous spaces", where recreational and political activities are organized.

\section{Disclosure statement}

No potential conflict of interest was reported by the authors.

\section{References}

Akcapar, Sebnem Koser. 2009. "Turkish Associations in the United States: Towards Building a Transnational Identity." Turkish Studies 10 (2): 165-193. doi:10.1080/ 14683840902863996. 
Alexander, Claire. 2013. "Contested Memories: The Shahid Minar and the Struggle for Diasporic Space." Ethnic and Racial Studies 36 (4): 590-610. doi:0.1080/01419870. 2012.674542.

Alexander, Claire, Chatterji Joya, and Annu Jalais. 2016. The Bengal Diaspora: Rethinking Muslim Migration. London: Routledge.

Ambrosini, Maurizio. 2014. "Networking, protesta, advocacy, aiuto. La società civile italiana e gli immigrati [Networking, Protest, Advocacy, Help. Italian Civil Society and Migrants]." Mondi Migranti 3: 201-222.

Attanasio, Paolo, and Facchini, Andrea. 2004. "Rappresentanza politica e diritto di voto [Political Representation and Voting Rights]." In Immigrazione. Dossier statistico [Statistical Dossier on Migration], edited by Caritas-Migrantes, 186-195. Roma: Idos.

Basch, Linda, Nina Glick Schiller, and Christina Szanton Blanc. 1994. Nations Unbound: Transnational Projects, Postcolonial Predicaments, and Deterritorialized Nation-States. Philadelphia, PA: Gordon and Breach.

Boccagni, Paolo. 2012. "La partecipazione politica degli immigrati: dal dibattito internazionale al caso italiano [The Political Participation of Migrants: From the International Debate to the Italian Case]." In Governare città plurali. Politiche locali di integrazione per gli immigrati in Europa [Governing Plural Cities. Local Migrant Integration Policies in Europe], edited by Maurizio Ambrosini, 69-97. Milano: Franco Angeli.

Camozzi, llenya. 2008. Lo spazio del riconoscimento. Forme di associazionismo migratorio a Milano [The Recognition Space. Forms of Migratory Association in Milan]. Bologna: II Mulino.

Caselli, Marco. 2006. Le associazioni di migranti in provincia di Milano [Migrant Association in the Province of Milan]. Milano: Franco Angeli.

Cesari, Jocelyne. 2005. "Mosque Conflicts in European Cities: Introduction." Journal of Ethnic and Migration Studies 31 (6): 1015-1024.

Cheran, Rudramoorthy. 2004. "Diaspora Circulation and Transnationalism as Agents for Change in the Post Conflict Zones of Sri Lanka." In Wenn es in deir Heimat um Krieg und Frieden geht. Die roller der Diaspora in Krisenentwicklung und ziviler Konfliktbearbeitung [When It Comes to war and Peace in Their Homeland. The Role of the Diaspora in Development Crisis and Civilian Conflict], edited by Calließ Jörg, 263-280. Rehberg-Loccum: Evangelische Accademie Loccum.

Cohen, Robin. 2008. Global Diasporas: An Introduction. London: Routledge.

Della Puppa, Francesco. 2014. Uomini in movimento. II lavoro della maschilità tra Bangladesh e Italia [Men on the Move. The Work of Masculinity Between Bangladesh and Italy]. Torino: Rosenberg \& Sellier.

Della Puppa, Francesco. 2018. "Ambivalences of the Emotional Logics of Migration and Family Reunification: Emotions, Experiences and Aspirations of Bangladeshi Husbands and Wives in Italy." Identities. Global Studies in Culture and Power 25 (3). doi:10.1080/1070289X.2016.1238381.

Della Puppa, Francesco, and King, Russell. 2018. "The New 'Twice Migrants': Motivations, Experiences and Disillusionments of Italian-Bangladeshis Relocating to London." Journal of Ethnic and Migration Studies. doi:10.1080/1369183X.2018. 1438251

Eade, John, Isabelle Fremeaux, and David Garbin. 2002. "The Political Construction of Diasporic Communities in the Global City." In Imagined Londons, edited by Gilbert Pamela, 969-988. Albany, NY: Suny Press.

Eade, John, and David Garbin. 2006. "Competing Visions of Identity and Space: Bangladeshi Muslims in Britain." Contemporary South Asia 15 (2): 181-193. doi:10. 1080/0958493060095529. 
Faist, Thomas. 2008. "Migrants as Transnational Development Agents: An Inquiry Into the Newest Round of the Migration-Development Nexus." Population, Space and Place 14 (1): 21-42. doi:10.1002/psp.47.

Gardner, Katy. 1995. Global Migrants, Local Lives. Migration and Transformation in Rural Bangladesh. Oxford: Oxford University Press.

Glick Schiller, Nina, Linda Basch, and Cristina Szanton-Blanc. 1995. "From Immigrant to Transmigrant: Theorizing Transnational Migration." Anthropological Quarterly 68 (1): 48-63. doi:10.2307/3317464.

Guarnizo, Luis Eduardo. 2003. "The Economics of Transnational Living." International Migration Review 37 (3): 666-699. doi:10.1111/j.1747-7379.2003.tb00154.x.

Kelly, Melissa. 2011. "Transnational Diasporic Identities: Unity and Diversity in IranianFocused Organizations in Sweden." Comparative Studies of South Asia, Africa and the Middle East 31 (2): 443-454. doi:10.1215/1089201X-1264343.

Kibria, Nazli. 2011. Muslims in Motion. Islam and National Identity in the Bangladeshi Diaspora. New Brunswick: Rutgers University Press.

King, Russell, and Melanie Knights. 1994. "Bangladeshis in Rome. A Case of Migratory Opportunism." In Population, Migration and Changing World Order, edited by Taylor William, Gould Spankie, and Findlay Allan, 127-144. New York: John Wiley and Sons.

Kosic, Ankica, and Anna Triandafyllidou. 2005. Active Civic Participation of Immigrants in Italy. Oldenburg: POLITIS Research Report.

Levitt, Peggy, and Nina Glick Schiller. 2004. "Conceptualizing Simultaneity: A Transnational Social Field Perspective on Society." International Migration Review 38 (3): 1002-1039. doi:10.1111/j.1747-7379.2004.tb00227.x.

Mantovan, Claudia. 2007. Immigrazione e cittadinanza. Auto-organizzazione e partecipazione dei migranti in Italia [Migration and Citizenship. The Self-Organization and Participation of Migrants in Italy]. Milano: Franco Angeli.

Marquez, Benjamin. 2001. "Choosing Issues, Choosing Sides: Constructing Identities in Mexican-American Social Movement Organizations." Ethnic and Racial Studies 24 (2): 218-235. doi:10.1080/01419870020023427.

Morad, Mohammad, and Jure Gombač. 2015. “Transmigrants, Transnational Linkages and Ways of Belonging: The Case of Bangladeshi Migrants in Italy." Dve Domovini/ Two Homelands 41 (1): 61-76.

Morad, Mohammad, and Jure Gombač. 2018. "'Probashi' in Italy. New Destinations: Trends, Origins and Profiles of Bangladeshi Migrants in Padova and Cadoneghe." Dve Domovini/Two Homelands 47 (1): 37-52.

Olwig, Karen Fog. 2003. "Transnational Socio- Cultural Systems and Ethnographic Research: Views from an Extended Field Site." International Migration Review 37 (3): 787-811. doi:10.1111/j.1747-7379.2003.tb00158.x.

Orozco, Manuel, and Rebecca Rouse. 2013. Migrant Hometown Associations and Opportunities for Development. Washington, DC: Migration Policy Institute.

Owusu, Thomas. 2000. "The Role of Ghanaian Immigrant Associations in Toronto, Canada." International Migration Review 34 (4): 1155-1181. doi:10.2307/2675978.

Palidda, Rita, and Consoli, Maria Teresa. 2006. "L'associazionismo degli immigrati tra solidarietà e integrazione [Migrant Associations Between Solidarity and Integration]." In Stranieri in Italia. Reti migranti [Foreigners in Italy. Migrant Networks], edited by Francesca Decimo e Giuseppe Sciortino, 115-149. Bologna: Il Mulino.

Pirkkalainen, Päivi. 2013. "Transnational Responsibilities and Multi-Sited Strategies: Voluntary Associations of Somali Diaspora in Finland." PhD thesis. University of Jyväskylä. 
Priori, Andrea. 2010. "Via segreta delle etnie [The Secret Life of Ethnicities]." Zapruder 21 (2): 38-54.

Priori, Andrea. 2012. Romer probashira. Reti sociali e itinerari transnazionali bangladesi a Roma [Romer Probashira. The Social Networks and Transnational Itineraries of Bangladeshis in Rome]. Roma: Meti.

Rex, John, Joly Danièle, and Wilpert Czarina. 1987. Immigrant Associations in Europe. Aldershot: Gower.

Saint-Blanc, Chantal, and Ottavia Schmidt di Friedberg. 2005. "Why Are Mosques a Problem? Local Politics and Fear of Islam in Northern Italy." Journal of Ethnic and Migration Studies 31 (6): 1083-1104.

Sardinha, João. 2005. Cape Verdean Associations in the Metropolitan Area of Lisbon: Their Role in Integration. Sussex Centre for Migration Research. Working Paper, 26.

Schrover, Marlou, and Floris Vermeulen. 2005. "Immigrant Organisations." Journal of Ethnic and Migration Studies 31 (5): 823-832. doi:10.1080/13691830500177792.

Vertovec, Steven. 1997. “Three Meanings of 'Diaspora' Exemplified Among South Asian Religions." Diaspora: A Journal of Transnational Studies 6 (3): 277-299. doi:10.1353/ dsp.1997.0010.

Zeitlyn, Benjamin. 2006. Migration from Bangladesh to Italy and Spain. Dhaka: Rmmru. 